\title{
Poverty in New Zealand: Who is Most Affected, What are the Effects on Students, and How can the Issues be Overcome?
}

\author{
Lesley Burkett
}

\section{Position Paper}

Keywords: behaviour, education, equity, learning, poverty, socio-economic status

\begin{abstract}
Students from low socio-economic backgrounds in New Zealand face many disadvantages when it comes to education, and, despite government initiatives, the disparity between the poor and the well-off continues to grow in this country. New Zealand is among several countries where income inequalities are large and the impact of socio-economic background on learning outcomes is also large (OECD, 2010).
\end{abstract}

The literature in New Zealand, and overseas, regarding the effects of poverty on education is varied and extensive. This position paper discusses these effects on the learning and behaviour of students and considers what ethnicities are most at-risk as a result. Enablers and barriers to overcoming disadvantages associated with low socio-economic status (SES) background are then reviewed.

\section{INTRODUCTION}

According to the Statistics New Zealand report, Vulnerable children and families: Some findings from the New Zealand General Social Survey one in four children under the age of $18(268,000)$ live in households defined as medium- or high-risk (Statistics New Zealand, 2012). Households in the high-risk group include those receiving benefit income, sole parent households, large households, households with Māori respondents, and households where the mother had given birth before the age of 21 . Six per cent $(67,000)$ of children live in high-risk households with five or more risk factors. The report also concluded that Māori were over-represented in high-risk households. Children who live in high-risk households are more likely to have poor health and nutrition. Low levels of parental education and stress common in the high-risk household can lead to poor parenting skills and a learning environment with limited stimulation (Statistics New Zealand, 2012).
Research has shown that children who are born into poor families may have poorer levels of educational attainment or cognitive function. Low levels of educational attainment may lead to poor employment opportunities and reduced income in adulthood, and poverty is 'transmitted' to the next generation (Save the Children, 2009). However, The Competent Children, Competent Learners longitudinal study in New Zealand found that what teachers and parents do, their interactions and the opportunities they provide, could make a positive difference to children's achievement at school despite the challenges of poverty (Children's Commissioner, 2013).

In this position paper I will discuss the effects poverty has on learning and behaviour, who is most at-risk in New Zealand, and the barriers and enablers schools and families face when trying to interrupt the cycle of poverty (Save the Children, 2009). Henderson (2013) used a similar format to discuss Māori potential and the barriers to creating culturally-responsive learning environments in Aotearoa/New Zealand. Her paper inspired me to research the affects of poverty on students' learning and behaviour and the link between low SES and ethnicity.

\section{What Ethnicities are Most Affected by Socio- economic Disadvantage in New Zealand?}

Socio-economic status (SES) is a measure of social and economic factors. Children are assigned SES labels according to their level of household income and their parents' educational qualifications (Children's Commissioner, 2013). Ethnicity and SES are often closely linked and in New Zealand, Māori and Pasifika people are more likely to have a lower SES, not because it is a disadvantage to come from these ethnic groups, but because of inequitable distribution of income and education across $\mathrm{New}$ Zealand's population (Children's Commissioner, 2013). Thrupp (2006) states that schools may actively maintain inequality as they quietly sort people into winners and losers based on their initial cultural characteristics, thereby maintaining the dominance of the middle classes. He goes on to say that low 
SES families are not only poor, they are typically in a subordinate social class position within society. It follows, then, that if Māori and Pasifika people are the ethnicities most at-risk of poverty in our society, then teachers, many of whom are from the dominant middle classes, will need to know how to effectively engage and teach these students in their classroom.

According to Alton-Lee (2003), by 2040, current projections predict that the majority of students in New Zealand primary schools will be Māori and Pasifika. This change will occur within the working life of teachers who are currently being trained or inducted into teaching. Furthermore, classrooms are growing increasingly more diverse with many students identifying with many different ethnicities (Alton-Lee, 2003).

\section{What Effect Does Coming From a Low Socio- economic Background Have on Learning and Behaviour?}

The educationalist Helen Ladd writes: "... study after study has demonstrated that children from disadvantaged households perform less-well in school on average than those from more advantaged households" (cited in Children's Commissioner, 2013, p. 2).

According to Perry (2012), low SES families have limited finances and therefore less access to books, educational toys, and educational outings. There is often increased stress in the low socio-economic home, which in turn makes it more difficult to provide a cognitively stimulating environment (Perry, 2012). This is particularly important in single-parent homes, where Nelson et al., (2007) have found that maternal depression is a significant factor contributing to behaviour problems in young children. Letourneau, Duffet-Leger, Levac, Watson and Young-Morris (2011) found in their meta-analysis of ethnic diversity, socio-economic status and child development, that the lower the SES the higher the prevalence of externalising (aggressive) and internalising (depression) behaviour.

Hook, Lawson and Farah (2013) looked at the relationship between socio-economic status and executive function (the ability to actively direct, control and regulate thoughts and behaviour) and found that children from higher socio-economic families showed better executive function. They have also shown that the level of executive function is a predictor of school achievement and is also associated with mental health outcomes. However, the parent-child relationship and its ability to buffer stress can mediate the association between childhood SES and executive function. These authors suggested the need for social policies which fund programmes and interventions that reduce parental stress and increase children's access to cognitively-stimulating activities and resources.

Furthermore, an examination of a 25-year longitudinal study of over 1,000 New Zealand children found that the educational aspirations of families and positive parent-child interactions played a large role in children from low SES backgrounds succeeding at school (Fergusson, Horwood \& Boden, 2008). This supported the Best Evidence Synthesis: The Complexity of Community and Family Influences on Children's Achievement in New Zealand which reported that regardless of SES background, families with high levels of educational expectations have the most positive effects on their children's achievement at senior school level (Biddulph, Biddulph \&

Biddulph, 2003). The evidence indicated that most parents were prepared to help their children as far as their resources permitted.

In New Zealand and overseas, studies have found that lower SES children are less likely to have access to a stimulating curriculum, and more likely to experience less-qualified teachers with lower expectations (Perry, 2012). In some communities this can lead to a kind of socio-economic segregation or "white flight" where higher SES families send their children out of town to schools rather than to the local one. This may lead to a 'spiral of decline' where the quality of education schools can provide declines as lower SES areas lose their 'brightest' students (Perry, 2012; Thrupp, 2006).

Disturbingly, an Australian study found the quality of pedagogy was lower in schools with large numbers of students from disadvantaged backgrounds (Griffiths, Amosa, Ladwig \& Gore, 2007). Furthermore, studies have also found that the school-level SES had a detrimental effect on students as they progressed through school (Holmes-Smith 2006, cited in Buckingham, Wheldall \& Beaman-Wheldall, 2013). A study by Cassan and Kingdom (cited in Buckingham et al., 2013) put it succinctly: students from lower SES backgrounds were often found in lower-quality schools.

Jensen (2013) discusses seven differences between middle-class and low-income students showing up at school: health and nutrition; vocabulary; effort, hope and growth mindset; cognition; relationships, and distress. Jensen provides advice about how schools can address these differences, however, he makes it clear that without teachers getting to know their students well, addressing these seven factors will mean little.

Thrupp (2006) questions whether the onus should be on schools to solve the problem. While schools can make a difference there is still a role 
for government to devise long-range strategies to eliminate poverty. However, Thrupp believes schools are not benign because they can help to reproduce social inequalities through the 'hidden curriculum' of schooling which is set up for the white middle classes. What can teachers do to encourage enablers and respond to barriers so as to address SES in relation to ethnicity? Studies have shown that positive home/school relationships and parents' active support of their children's education can make a difference to achievement at school.

\section{WHAT ARE THE ENABLERS TO SCHOOLS AND PARENTS WORKING TOGETHER?}

\section{Building Relationships}

For schools to make positive links with families they need to know about their students' lives outside of school and families' expectations of what it is that schools can achieve (GroundwaterSmith, 2011). Schools must work from a position of whanaungatanga (making connections) and get to know the iwi and hapu in their areas, talk to kaumatua and then, when ready, experience parts of that world when they can (Macfarlane, 2004). Macfarlane goes on to state that parental involvement is a must if schools wish to lessen academic and behavioural disadvantages, and then lists several ways of interacting with Māori parents. Parents of students experiencing learning and behaviour difficulties also have aspirations for their futures. As educators, it is important that we do not kill these dreams (Macfarlane, 2004, p. 69). Effective engagement of Pasifika parents and communities also rely on relationships which must be fostered among all partners (Gorinski \& Fraser, 2006, cited in Ferguson et al., 2008, p. 30).

When family and school form positive relationships, outcomes for students quickly improve (Berryman, cited in Bottrell \& Goodwin, 2011). To build a relationship of trust, schools need to actively construct knowledge with the community and be willing to listen and learn, and schools must allow families to be self-determining: to let families decide how they will be involved in schools (Berryman \& Bishop, 2011). When all parties construct and share common visions and goals it is most effective for partnerships (Children's Commissioner, 2013).

The New Zealand Education Review Office (ERO) (2008) found that when schools with diverse communities started to recognise the cultural identity and values of students, their parents and their families, then those cultural identities and values started to appear in the school culture and practices. Schools which do this well identified the skills and expertise in their communities and valued them. They held regular meetings involving parents and whānau and this had a positive effect on engagement. Key people from either the school or the wider community led these meetings and provided a bridge for parents to come into school. This built parents' confidence, especially if schooling had not been a positive experience for them in the past. The strengthening of the school, whānau and community partnership then benefited student learning and well-being.

It is up to schools to reach out to families who, for many reasons, may find schools inhospitable places. However, schools also need to reach out to those community agencies that support families (Groundwater-Smith, 2011). This is exactly how one school in Christchurch changed the way in which it engaged with its community after the tragedy of the Canterbury earthquakes. Principal Christine Harris (2013) discussed how her approach to engaging whānau changed dramatically after the earthquakes. Her approach changed as she, and the teachers at her school, started to meet the needs of the community, which then built up a considerable amount of trust with whānau. At the same time, they were building 'strong and respectful' relationships with support agencies. Harris concluded that if there was a concept that encapsulated the learning she and her team experienced it was the importance of developing relationships above all else. She said relational trust began to evolve in her school's diverse community as the school reached out to all members of the community in need. Harris also talked of the school meeting the holistic needs of the student first which developed a strong sense of ako (collaborative and reciprocal approach) and awhinatanga (interpersonal care and support).

Harris and her teachers showed that they were committed to their community and cared about its social and emotional stability, and that they were willing to embrace diverse cultures and value cultural exchanges at both the personal and pedagogical levels (Munns, Sawyer \& Cole, 2013).

\section{Ministry of Education Resources}

Ministry of Education (MOE) resources are many and varied, however, too often they are not taken up by schools. There needs to be teachers and leaders within the schools with cross-cultural competency to ensure the likes of Ministry of Education resources such as Ka Hikitia and Tātaiako are implemented effectively (Henderson, 2013).

Tapaleao (2014) attributed an increase in Māori and Pasifika students achieving NCEA 2 to a number of 
MOE initiatives introduced in schools. These included mentoring programmes and homework centres such as the Power Up Pasifika and Starpath projects. The Starpath project, launched by the University of Auckland in 2005, is research-based and aims to help high school students from low-to mid-socioeconomic backgrounds achieve. Both projects use mentors to guide students in their learning and educational aspirations. Mentors and teachers offer their services to students in Power Up stations around Auckland and Wellington free-of-charge. The Power Up programme is uniquely Pacific in that the homework centre invites parents and families to come in and act as support-figures for their children. They are held in places familiar to Pacific families such as churches and community halls and a meal is provided afterwards (Tapaleao, 2014).

\section{Culturally Responsive and Empathetic Teachers/Educators}

Empathetic teachers create a culture of care in their classrooms and respond to their students' culture positively. They are aware of and understand Article 2 of the Treaty of Waitangi which allows Māori the right to protect their knowledge, language, values, beliefs and practices (Macfarlane, Glynn, Cavanagh \& Bateman, 2007). When teachers in New Zealand get their bi-cultural relationship right then multi-cultural relationships will do likewise.

Empathetic teachers promote self-efficacy in their classrooms and this may lead to higher academic achievement in low SES schools. Teachers need to find the "slightest thing" to help students believe in themselves as learners (Munns et al., 2013; Perry, 2012).

While Durie (2003) does not discount socioeconomic factors, he believes the essential difference is that Māori live at the interface between two worlds: te ao Māori (the Māori world) and te ao whānui (the wider global society). Therefore, it is the way these two views impact on each other that is the determinant factor for educational success, however, that does not mean socio-economic factors are unimportant (Durie, 2003).

Culturally-responsive educators will help students appreciate their own place in their community while at the same time opening up the possibilities of a wider world (Munns et al., 2013). It is in the space between these two worlds that culturally-responsive educators, including Resource Teachers: Learning and Behaviour, must walk and help to facilitate the resilience students and teachers will need to navigate a world they don't necessarily live in every day.

\section{WHAT ARE THE BARRIERS TO SCHOOLS AND PARENTS WORKING TOGETHER?}

\section{Lack of Knowledge of Te Ao Māori (The Māori World)}

Educational policy, teaching practice and key performance indicators for staff must match the Māori world view reality (Durie, 2003). Barnes, Hutchings, Taupo \& Bright (2012) agree, stating that some teacher-practice demonstrated a low level of awareness of Māori world views and more needed to be done to train and professionally develop teachers and school leaders so as to improve engagement with Māori students (Barnes, et al, 2012).

Research undertaken in Colorado into family-school partnerships (FSP) also highlighted the need for training teachers to be taught ways of engaging and interacting positively with diverse families (Sullivan, Miller, Lines \& Hermanutz, 2009).

\section{Lack of Knowledge of the Pasifika World}

The word Pasifika is used to recognise the multiethnic, heterogeneous group of Pasifika peoples which comprises different languages and cultures (Ferguson, et al., 2008). Pasifika peoples is a collective term used to refer to the cultures of Samoa, Cook Islands, Tonga, Niue, Tokelau, Fiji, Solomon Islands, Tuvalu, and other Pasifika or mixed heritages.

Ferguson et al., (2008) state that an understanding of the immigration history of Pasifika peoples to New Zealand is critical for all those working in education because it may enable teachers and educators to better-appreciate the role of schooling in replicating wider society, as well as assist in perceiving students as having complex social identities.

\section{Deficit-Theorising and Differences in Values}

Some teachers tend to blame students, or their socioeconomic background, for learning and behaviour difficulties and so problems are often attributed to students' weaknesses and not to the teaching method, curriculum or teacher-student relationship. Teachers need to look at their own pedagogy and not dwell on the supposed inadequacies of their students (Munns et al., 2013). Often there are differences in values between the school and parents that can lead to communication breakdown. Gillanders, McKinney and Ritchie (2012) found parents praised teachers who communicated with them positively about their child as well as the things their children needed to work on.

\section{Lack of Cross-Cultural Skills}

Many teachers do not have adequate knowledge and understanding of te reo me ngā tikanga Māori and the history and cultures of Pasifika peoples, and 
teacher training institutions need to ensure this is taught (Ferguson et al., 2008; Gillanders, McKinney \& Ritchie, 2013). If teachers and school leaders cannot step outside their own culture and engage with an 'other' in a cultural partnership, it is highly unlikely that the engagement with whānau and community will occur (Henderson, 2013). In New Zealand it is very easy to not have to step outside of the eurocentric culture and this mono-cultural lens colours everything people do, their values, their professional practice, and the way they live.

\section{CONCLUSION}

Coming from a low SES background should not be a precursor for not doing well academically. Those working in education need to be aware of the issues faced by children and families from low SES backgrounds. They need to upskill in cross-cultural competency and learn more about the Māori and Pasifika worlds because these are the ethnicities most-affected by poverty in New Zealand. Upskilling in cross-cultural competency is a must for all educators because the population in our schools is going to continue to become more diverse (Alton-Lee, 2003). Evidence shows teaching that is responsive to student diversity can have very positive impacts on both low and high achievers. Therefore, if teachers can help low SES students achieve academically, then they may go on to higher learning and gain better jobs with better pay, which can then break the poverty cycle. Key to this outcome is building positive relationships with students and their whānau from lower SES homes: it goes hand-in-hand with forming strong and respectful relationships with those agencies working with family and whānau.

\section{REFERENCES:}

Alton-Lee, A. (2003). Quality teaching for diverse students in schooling: Best evidence synthesis. Wellington: Ministry of Education.

Barnes, A., Hutchings, J., Taupo, K., \& Bright, N. (2012). Critical issues for whānau in Englishmedium schools. set: Research Information for Teachers, 2, 12-19.

Berryman, M., \& Bishop, R. (2011). Culturally responsive relations. In D. Botrell \& S. Goodwin (Eds.), Schools, Communities and Social Inclusion (pp. 50-63). Malaysia: Palgrave Macmillan.

Biddulph, F., Biddulph, J., \& Biddulph, C. (2003). The complexity of community and family influences on children's achievement in New Zealand: Best evidence synthesis. Wellington: Ministry of Education.
Bottrell, D., \& Goodwin, S. (2011). Schools, communities and social inclusion. South Yarra, Australia: Palgrave MacMillan.

Buckingham, J., Wheldall, K., \& Beaman-Wheldall (2013). Why poor children are more likely to become poor readers: The school years. Australian Journal of Education. Retrieved from http://aed. sagepub.com/content/57/3/190

Children's Commissioner (2013). Parents', families' and whānau contributions to educational success. Wellington.

Durie, M. (2003). Māori educational advancement at the interface between te ao māori and te ao whānui. Retrieved from: http://www.waitakere. govt.nz/AbtCnl/ct/pdf/taumata2003/140403att.pdf

Education Review Office (2008). Partners in learning: Schools' engagement with parents, whānau and communities. Wellington.

Ferguson, P.B., Gorinski, R., Wendt Samu, T., \& Mara, D. (2008). Literature Review on the experiences of Pasifika learners in the classroom. Wellington: Ministry of Education.

Fergusson, D., Horwood, J., \& Boden, J. (2008). The transmission of social inequality: Examination of the linkages between family socioeconomic status in childhood and educational achievement in young adulthood. ScienceDirect, 277-295.

Gillanders, C., McKinney, M., \& Ritchie, S. (2012). What kind of school would you like for your children? Exploring minority mothers' beliefs to promote home-school partnerships. Early Childhood Education Journal, 40, 285-294.

Griffiths, T., Amosa, W., Ladwig, J., \& Gore, J. (2007). Equity and pedagogy: Familiar patterns and QT based possibilities. Paper presented at the Australian Association for Research in Education conference. Retrieved from: http://strongersmarter. com.au/wp-content/uploads/2013/01/gri07282.pdf

Groundwater-Smith, S. (2011). Connecting to community: A two way street. In D. Botrell \& S. Goodwin (Eds.), Schools, Communities and Social Inclusion (pp. 50-63). Malaysia: Palgrave Macmillan.

Harris, C. (2013). From the rubble: Improving community and school engagement. Journal of Educational leadership, Policy and Practice, 28(1), 83-94.

Henderson, L. (2013). Māori potential: Barriers to creating culturally-responsive learning environments in Aotearoa/New Zealand: Te timatanga o te ara - Kei whea te ara? Kairaranga, 14(2), 10-15. 
Hook, C.J., Lawson, G.M., \& Farah, M.J. (2013). Socioeconomic status and the development of executive function. Encyclopedia on Early Childhood Development. Retrieved June 23, 2014 from: http://www.child-encyclopedia.com/ documents/Hook-Lawson-FarahANGxp1.pdf

Jensen, E. (2013). How poverty affects classroom engagement. Educational Leadership, 70(8), 24-30.

Letourneau, N., Duffet-Leger, L., Levac, L., Watson, B., \& Young-Morris, C. (2011). Socioeconomic status and child development: A metaanalysis. Journal of Emotional and Behavioural Disorders,21 (3), 211-223.

Macfarlane, A. (2004). Kia hiwa ra! Listen to culture - Māori students' plea to educators. Wellington: New Zealand Council for Educational Research.

Macfarlane, A., Glynn, T., Cavanagh, T., \& Bateman, S. (2007). Creating culturally safe schools for Māori students. The Australian Journal of Indigenous Education, 36, 65-76.

Ministry of Education (2013). Frameworks for bicultural education. He anga mō te mātauranga ahurea rua. Retrieved from: http://www.educate. ece.govt.nz.

Ministry of Education (2011). Tātaiako. Cultural competencies for teachers of Māori learners. Wellington: Author.

Munns, G., Sawyer, W., \& Cole, B. (2013). Exemplary teachers of students in poverty. New York: Routledge.

Nelson, R., Stage, S., Duppong-Hurley, K., Synhorst, L., \& Epstein, M. (2007). Risk factors predictive of the problem behaviour of children at risk for emotional and behavioural disorders. Exceptional Children, 73, (3), 367-379.

OECD (2010), PISA 2009 results. Overcoming social background: Equity in learning opportunities and outcomes (Volume II). OECD Publishing.

Perry, L. (2012). Causes and effects of school socioeconomic composition? A review of the literature. Education and Society, 30(1), 19-35.

Save the Children (2009). Helping families support children's success at school. Retrieved from: http:// www.savethechildren.org.uk/resources/onlinelibrary/helping-families-support-childrens-successat-school

Statistics New Zealand (2012). Vulnerable children and families: Some findings from the New Zealand general social survey. Wellington, NZ: Statistics NZ.
Sullivan, E., Miller, G., Lines, C., \& Hermanutz, K. (2009). Preparing Colorado educators to partner with families in a multi-tiered system of supports. Retrieved from: http://www.cde.state.co.us/sites/ default/files/documents/rti/spdg/downloads/pdf/ ihe_finalspdgreport.pdf

Tapaleao, V. (2014). Closing the gaps: Māori-Pacific report card - Good but could do better. New Zealand Herald [March 19 Online]. Retrieved from: http://www.nzherald.co.nz/news/print. cfm?objectid $=11222017$

Thrupp, M. (2006). Improving the schooling chances of New Zealand's poorest children: Policy and community challenges. Presentation to the AGM of the Child Poverty Group, Auckland, New Zealand.

\section{AUTHOR PROFILE}

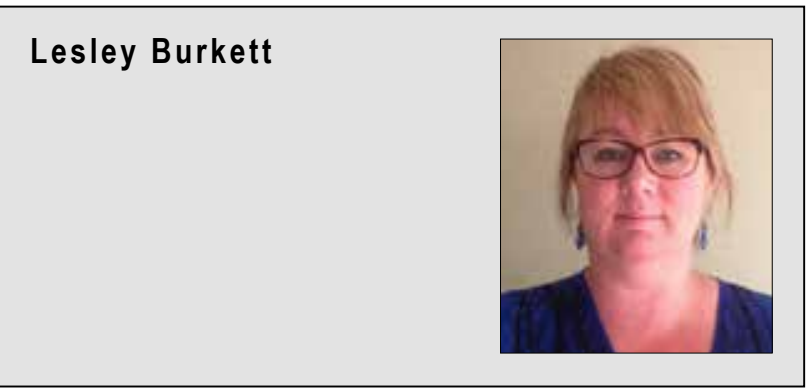

Lesley Burkett is an RTLB working for Hei Huruhuru, Cluster 17, and is based at Taumarunui High School. She has been working as an RTLB for one year and is currently in the first year of her Specialist Teaching: Learning and Behaviour post graduate degree.

Prior to becoming an RTLB, Lesley worked for eight years as a primary school teacher in the Taumarunui area in schools assigned decile ratings of 1 through to 3. She describes herself as "tuturu Taumarunui" (staunchly Taumarunui) and has a passion for working with the education community to help young people succeed.

\section{Email:}

lesley.burkett@taumarunuihighschool.co.nz 